\title{
Carbon and nutrient stocks of three Fabaceae trees used for forest restoration and subjected to fertilization in Amazonia
}

\author{
ROBERTO K. JAQUETTI and JOSÉ FRANCISCO C. GONÇALVES \\ National Institute for Research in Amazonia (INPA), Laboratory of Plant Physiology and \\ Biochemistry, Ave. André Araújo, 2936, Aleixo, 69011-970 Manaus, AM, Brazil
}

Manuscript received on October 25, 2016; accepted for publication on March 16, 2017

\begin{abstract}
Amazonia is crucial to global carbon cycle. Deforestation continues to be one of the main causes of the release of $\mathrm{C}$ into the atmosphere, but forest restoration plantations can reverse this scenario. However, there is still diffuse information about the $\mathrm{C}$ and nutrient stocks in the vegetation biomass. We investigated the carbon and nutrient stocks of Fabaceae trees (Inga edulis, Schizolobium amazonicum and Dipteryx odorata) subjected to fertilization treatments (T1 - no fertilization; T2 - chemical; T3 - organic; and T4 - organic and chemical fertilization) in a degraded area of the Balbina Hydroelectric Dam, AM Brazil. As an early successional species, I. edulis stocked more $\mathrm{C}$ and nutrients than the other two species independent of the fertilization treatment, and S. amazonicum stocked more C than D. odorata under T1 and T4. The mixed species plantation had the potential to stock $4.1 \mathrm{Mg} \mathrm{C}^{-1}$ year $^{-1}$, while I. edulis alone could stock 9.4 Mg Cha $\mathrm{Mear}^{-1}$. Mixing species that rapidly assimilate $\mathrm{C}$ and are of significant ecological and commercial value (e.g., Fabaceae trees) represents a good way to restore degraded areas. Our results suggest that the tested species be used for forest restoration in Amazonia.
\end{abstract}

Key words: biomass, degraded ecosystems, plant nutrition, tropical tree species.

\section{INTRODUCTION}

The global climate is changing; more intense and frequent El Niños and rising temperatures are becoming reality (Malhi et al. 2008, Moss et al. 2010, Davidson et al. 2012, Kintisch 2016). In many ways, deforestation and forest degradation have exacerbated these changes by releasing $\mathrm{CO}_{2}$ and other greenhouse gases (GHGs) that were previously stored in the forest biomass into the atmosphere (Houghton 2005). Tropical forests have

Correspondence to: José Francisco de Carvalho Gonçalves E-mail: jfc@inpa.gov.br a significant capacity to store $\mathrm{C}$ and other nutrients in their biomass, and the $\mathrm{C}$ can then be released through burning or decomposition, primarily from conversion into pastures and agricultural fields, which are the primary causes of forest degradation in Amazonia (Houghton et al. 2000, Achard et al. 2002, Karsten et al. 2013). Although some studies have shown that almost $20 \%$ of the original Amazonian forest cover has disappeared, forest degradation may be higher depending on the monitoring system (Asner et al. 2005, Davidson et al. 2012). 
Forest restoration plantations have the capacity to recover large amounts of $\mathrm{C}$ stocks in a short time while simultaneously producing goods and services (Ruiz-Jaen and Potvin 2011, Houghton 2012, Guariguata and Brancalion 2014), but the choice of species and their silvicultural traits is a fundamental aspect of this practice (Fang et al. 2007). A mixture of different ecological groups (pioneer and late-successional species) is desirable to better use the available resources and therefore enhance C stocks (Rodrigues et al. 2009).

Forest restoration is an effective way to restore biodiversity and $\mathrm{C}$ stocks, especially under severe degradation (Soares-Filho et al. 2014), but transcending ecosystem barriers is very difficult as non-adapted species can easily collapse and die (Rowland et al. 2015). The main obstacles to be overcome in the degraded ecosystems of the Amazon are high irradiance and temperatures, periods of drought and, especially, the low natural fertility of the soils that are the major limiting factor for $\mathrm{C}$ assimilation and plant growth (Gonçalves and Santos Junior 2005, Santos Junior et al. 2006, Ferreira et al. 2009, Jaquetti et al. 2014, 2016).

Therefore, the study of the use of different fertilization treatments in forest restoration and the responses of native species to these treatments is essential to develop planting designs that are capable of better utilizing available resources to increase stand-level productivity and individual tree growth rates, and the use of Fabaceae trees is important to achieve these objectives in degraded landscapes (Siddique et al. 2008). These species are well adapted to low nutrient availability and arid ecosystems, as they have developed the capacity to fix atmospheric nitrogen $(\mathrm{N})$ through bacterial symbiosis (Macedo et al. 2008, Joslin et al. 2011). Thus, they can rapidly rebuild $\mathrm{C}$ and $\mathrm{N}$ stocks through rapid biomass production (Tapia-Coral et al. 2005), which in turn is an excellent success indicator of forest restoration projects (Viana et al. 2014).
Despite the importance of understanding the responses of native species to different ecological conditions, a significant knowledge gap exists concerning the basic silviculture of tropical species, for both restorative and commercial purposes, in degraded areas of the Amazon (Ferreira et al. 2016). The potential for native tropical trees to assimilate and incorporate $\mathrm{C}$ and nutrients into their biomass is equally important, especially in the context climate change, as native tropical trees can mitigate the impacts of deforestation as well as be traded on the global $\mathrm{C}$ credit market (Gibbs et al. 2007, Ruiz-Jaen and Potvin 2011, Silva et al. 2011, Visseren-Hamakers et al. 2012).

To increase the understanding of $\mathrm{C}$ and nutrient stocks in trees in tropical forest restoration, we investigated the composition of the biomass of three Fabaceae tree species subjected to fertilization treatments (chemical and organic amendments) in a degraded area of central Amazonia.

\section{MATERIALS AND METHODS}

STUDY SITE, SPECIES DESCRIPTION AND FERTILIZATION TREATMENTS

This study was carried out in a degraded area within the Balbina Hydroelectric Dam Forest Restoration Project (01 $55^{\circ} 99^{\prime \prime} \mathrm{S}$ and 59 24'65”W) in the county of President Figueiredo in Central Amazonia, AM, Brazil. The study area covers a total of 6 hectares and was degraded in 1983 during dam construction, during which the natural vegetation of the area, characterized as "nonflooded dense forest," was completely removed. The blocks of this study were located in gaps between the vegetation, and shaded spots produced by natural islands of regeneration were avoided. The climate of the region is Af (tropical humid), according to the Köppen climate classification system, with $2,280 \mathrm{~mm}$ of precipitation annually and a mean annual temperature above $25^{\circ} \mathrm{C}$. The 
soil in the area is classified as yellow oxisol with high acidity and low natural fertility.

The beginning of the experiment was marked by the manual excavation of $30 \mathrm{~cm} \times 40 \mathrm{~cm}$-deep tree-planting holes using a straight spade modified with an iron cable; the distance between the seedlings was $2 \mathrm{~m} \times 2 \mathrm{~m}$. Fertilization treatments were performed fifteen days before planting and involved incorporating $50 \mathrm{~g}$ of lime, $150 \mathrm{~g}$ of Fosmag ${ }^{\circledR}$ Bunge chemical fertilizer (São Paulo, SP, Brazil: $4 \% \mathrm{~N}, 14 \% \mathrm{P}, 7 \% \mathrm{~K}, 11.5 \% \mathrm{Ca}, 2.7 \% \mathrm{Mg}$, $10.4 \% \mathrm{~S}, 0.07 \% \mathrm{~B}, 0.59 \% \mathrm{Zn}$ and $0.15 \% \mathrm{Cu}$ ) and $15 \mathrm{~g}$ of FTE BR-12 ${ }^{\circledR}$ Nutriplant (São Paulo, SP, Brazil: 7.1\% Ca, 5.7\% S, 1.8\% B, 0.8\% Cu, 2.0\% $\mathrm{Mn}, 0.1 \%$ Mo and $9.0 \% \mathrm{Zn}$ ) into the soil in all of the fertilization pits except for T1 (control), which was not fertilized throughout the experiment. The fertilization pits were only created during site preparation, so the period following fertilization of the T2, T3 and T4 treatments can be considered the post-planting fertilization period. The species were randomly placed within each block; three individual plants from three different species were fertilized according to one of four fertilization treatments for a total of 12 treatments per block, each of which was $144 \mathrm{~m}^{2}(12 \times 12 \mathrm{~m})$ in size. This protocol was replicated three times in each block, resulting in a total of 36 seedlings per block and a total of 216 experimental seedlings.

Individuals of three native Fabaceae species, tonka bean (Dipteryx odorata [(Aubl.) Willd.]), ice-cream bean tree (Inga edulis Mart.) and white faveira (Schizolobium amazonicum Huber ex Ducke), of uniform size ( $35 \mathrm{~cm}$ high for D. odorata, $40 \mathrm{~cm}$ for $I$. edulis and $30 \mathrm{~cm}$ for $S$. amazonicum) and health within the same species were selected, and the following fertilization scheme was used: T1) unfertilized (control), T2) post-planting chemical fertilization, T3) post-planting organic fertilization and T4) post-planting chemical and organic fertilization combined. Two additional applications were performed for the post-planting chemical fertilization treatments (T2 and T4), the first of which was performed four months after planting with the application of $50 \mathrm{~g}$ of lime, $150 \mathrm{~g}$ of Fosmag $^{\circledR}$ (the same formulation as above) and 15 $\mathrm{g}$ of FTE BR-12 ${ }^{\circledR}$ Nutriplant (the same formulation as above). The second application was performed 8 months after planting and consisted of $50 \mathrm{~g}$ of lime and $150 \mathrm{~g}$ of NPK 4-14- $8^{\circledR}$ Bunge chemical fertilizer (São Paulo, SP, Brazil: 4\% N, 14\% P and $8 \% \mathrm{~K})$. The chemical fertilizers were applied around the seedlings over an area that was $50 \mathrm{~cm}$ in diameter.

In treatments $\mathrm{T} 3$ and $\mathrm{T} 4$, branches and leaves were collected from the lower third of the fallow trees in the area, and the material was then manually chopped with a machete into 10 -cm-long pieces and applied to the bare soil without incorporation. The treatment areas were covered with a $25-\mathrm{cm}$ high layer of this green material. Two additional applications were also performed in the organic fertilization treatments. The first application was performed 10 days before planting and consisted of $12.4 \mathrm{~kg} \mathrm{~m}^{-2}$ (124.5 $\left.\mathrm{Mg} \mathrm{ha}^{-1}\right)$ of fresh mass, and the second application was performed 4 months after planting and consisted of $5.5 \mathrm{~kg} \mathrm{~m}^{-2}\left(55.2 \mathrm{Mg} \mathrm{ha}^{-1}\right)$ of fresh mass. Assuming that each plant covered an area of $4 \mathrm{~m}^{2}$, the first application consisted of approximately $13 \mathrm{~kg} \mathrm{C}, 290 \mathrm{~g} \mathrm{~N}, 11 \mathrm{~g} \mathrm{P}, 106 \mathrm{~g} \mathrm{~K}$, $144 \mathrm{~g} \mathrm{Ca}$ and $41 \mathrm{~g} \mathrm{Mg}$ per plant, and the second application consisted of approximately $6 \mathrm{~kg} \mathrm{C}, 131$ g N, 5 g P, 48 g K, 65 g Ca and 18 g Mg per plant.

The total amounts of nutrients applied per plant were as follows: T1) no fertilization; T2) $18 \mathrm{~g}$ N, 63 g P, 33 g K, 82 g Ca, 38 g Mg, 33 g S, 0.7 g $\mathrm{B}, 4.4 \mathrm{~g} \mathrm{Zn}, 0.7 \mathrm{~g} \mathrm{Cu}, 0.6 \mathrm{~g} \mathrm{Mn}$, and $0.03 \mathrm{~g} \mathrm{Mo}$; T3) $19 \mathrm{~kg} \mathrm{C}, 427 \mathrm{~g} \mathrm{~N}, 37 \mathrm{~g} \mathrm{P}, 164.5 \mathrm{~K}, 242 \mathrm{~g} \mathrm{Ca}, 73 \mathrm{~g}$ $\mathrm{Mg}, 16 \mathrm{~g} \mathrm{~S}, 0.4 \mathrm{~g} \mathrm{~B}, 2 \mathrm{~g} \mathrm{Zn}, 0.3 \mathrm{~g} \mathrm{Cu}, 0.3 \mathrm{Mn}$, and $0.015 \mathrm{~g} \mathrm{Mo}$; and T4) $19 \mathrm{~kg} \mathrm{C}, 445 \mathrm{~g} \mathrm{~N}, 100 \mathrm{~g} \mathrm{P}, 197$ g K, 324 g Ca, 111 g Mg, 49 g S, 1 g B, 6.4 g Zn, 1 $\mathrm{g} \mathrm{Cu}, 0.9 \mathrm{~g} \mathrm{Mn}$, and $0.045 \mathrm{~g} \mathrm{Mo.}$ 


\section{BIOMASS AND CARBON SEQUESTRATION RATE}

The biomass in each treatment was determined by randomly selecting one of the three replicates of each treatment in the six blocks $(n=6)$. The shoot was collected first and set aside, and the roots were subsequently collected by removing the soil within 50-100 $\mathrm{cm}$ of the base of each plant until the first roots were found. The surrounding area was then carefully excavated, and the roots were separated from the soil. The component leaves, stems and roots were separated from each plant and taken to the Laboratory of Soils and Plants of the National Institute of Amazonian Research (LSP - INPA); the roots were washed to remove all soil particles. The material was placed in a forced-ventilation oven $\left(65^{\circ} \mathrm{C}\right.$ for the leaves and fine roots, $105^{\circ} \mathrm{C}$ for the stems and coarse roots) until the material reached a constant weight, and after drying, the material was weighed using a digital scale (Mettler PM 30-K) with a precision of $0.01 \mathrm{~g}$ (Zhao et al. 2001, Schroth et al. 2002). The absolute growth rates in biomass $\left(\mathrm{AGR}_{\text {biomass }}\right)$ of the leaf, stem and root components were calculated as described by Hunt (1990) $\left(\mathrm{AGR}_{\text {biomass }}=\mathrm{W} 2-\mathrm{W} 1 / \mathrm{t} 2-\mathrm{t} 1\right)$, where $\mathrm{W} 1=$ initial weight; $\mathrm{W} 2$ = final weight; $\mathrm{t} 1$ = initial time; and $\mathrm{t} 2$ = final time. At harvest, 11 months after planting, I. edulis and $S$. amazonicum were, on average, 2.5 and $2.2 \mathrm{~m}$ in height and 7 and $5 \mathrm{~cm}$ in diameter, respectively, both in the T4 treatment, while the $D$. odorata individuals had mean T2 values of $1.3 \mathrm{~m}$ in height and $2 \mathrm{~cm}$ in diameter. The $\mathrm{C}$ content of each component was obtained by summing the biomass of each component and multiplying the total by a factor of 0.47 , which is the current suggestion for tropical angiosperm species by Thomas and Martin (2012).

\section{LEAF NUNTRIENT CONTENT AND ASSIMILATION}

To determine the macro-nutrient contents for each treatment, four healthy leaves that appeared fully expanded under full exposure to the sun were pre-selected from the middle third of the plants just before harvesting. The total $\mathrm{N}$ content was determined by the Kjeldahl method (Miyazawa et al. 2009), and the phosphorous content was determined by spectrophotometry at $725 \mathrm{~nm}$. The contents of other macro-nutrients $(\mathrm{K}, \mathrm{Ca}$ and $\mathrm{Mg}$ ) were determined by atomic absorption spectroscopy (Perkin-Elmer 1100B, Uberlingen, Germany) (Embrapa 2009).

\section{EXPERIMENTAL DESIGN AND STATISTICAL ANALYSIS}

The experiment was arranged in randomized blocks and consisted of 12 treatments involving a combination of 2 main factors (species $=3$ and fertilization $=4$ ); measurements were obtained from 3 replicates of each treatment. A two-way ANOVA was used to analyze the obtained data, and the means were separated using Duncan's multiple range test at the $p<0.05$ level of probability with the statistical program STATISTICA 7.0 (StatSoft Inc., Tulsa, OK, USA).

\section{RESULTS}

\section{CARBON SEQUESTRATION RATE}

Both factors, species and fertilization, were found to be statistically significant for all components. Under the T4 treatment, I. edulis (3768.7 $\mathrm{g} \mathrm{C}$ plant $^{-1}$ year $^{-1}$ ) accumulated almost 4 times more $\mathrm{C}$ in the entire plant than $S$. amazonicum $\left(962.8 \mathrm{~g} \mathrm{C}\right.$ plant $^{-1}$ year $^{-1}$ ) and more than 16 times that in D. odorata (226.5 g C plant $^{-1}$ year $^{-1}$ ). Under the T3 treatment, the value was 23 times higher for I. edulis (2215.3 $\mathrm{g} \mathrm{C}_{\text {plant }}{ }^{-1}$ year $^{-1}$ ) compared to D. odorata (95.3 g C plant $^{-1}$ year $\left.^{-1}\right)$ and almost 7 times higher relative to S. amazonicum (328.3 g C plant $^{-1}$ year ${ }^{-1}$ ) (Table I). The greatest difference between $S$. amazonicum and D. odorata was exhibited under the T4 treatment, where the former stocked greater than 4 times more $\mathrm{C}$ in the entire plant. Differences between the two species under the $\mathrm{T} 2$ treatment were not significant. 
TABLE I

Carbon sequestration rates of the different plant components, leaves, stems and roots, of three Amazonian leguminous trees under different fertilization treatments in a forest restoration plantation in an area degraded by the Balbina Hydroelectric Dam, AM, Brazil. T1 - no fertilization, T2 - chemical fertilization, T3 - organic fertilization, and T4 organic and chemical fertilization.

\begin{tabular}{|c|c|c|c|c|c|}
\hline \multirow{2}{*}{ Species } & \multirow{2}{*}{ Fertilization } & \multicolumn{4}{|c|}{ Variable } \\
\hline & & $\mathbf{C}_{\text {leaves }}$ & $\mathrm{C}_{\text {stems }}$ & $\mathrm{C}_{\text {roots }}$ & $\mathrm{C}_{\text {total }}$ \\
\hline \multirow{5}{*}{ D. odorata } & & \multicolumn{4}{|c|}{. } \\
\hline & $\mathrm{T} 1$ & $4.1 \pm 1.9 \mathrm{Cb}$ & $4.0 \pm 0.7 \mathrm{Cb}$ & $4.3 \pm 1.6 \mathrm{Cb}$ & $12.4 \pm 3.7 \mathrm{Cb}$ \\
\hline & $\mathrm{T} 2$ & $97.2 \pm 28.2 \mathrm{Ab}$ & $86.2 \pm 28.9 \mathrm{Ab}$ & $49.8 \pm 8.1 \mathrm{Ab}$ & $233.2 \pm 63.7 \mathrm{Ab}$ \\
\hline & $\mathrm{T} 3$ & $40.0 \pm 13.6 \mathrm{Bb}$ & $37.3 \pm 15.0 \mathrm{Bb}$ & $18.0 \pm 6.6 \mathrm{Bb}$ & $95.3 \pm 34.7 \mathrm{Bb}$ \\
\hline & $\mathrm{T} 4$ & $96.5 \pm 26.2 \mathrm{Ac}$ & $86.5 \pm 24.2 \mathrm{Ac}$ & $43.5 \pm 18.1 \mathrm{Ac}$ & $226.5 \pm 61.5 \mathrm{Ac}$ \\
\hline \multirow{4}{*}{ I. edulis } & $\mathrm{T} 1$ & $18.8 \pm 10.1 \mathrm{Ca}$ & $29.1 \pm 11.8 \mathrm{Ca}$ & $32.7 \pm 16.6 \mathrm{Ca}$ & $80.6 \pm 35.5 \mathrm{Ca}$ \\
\hline & $\mathrm{T} 2$ & $591.8 \pm 113.3 \mathrm{Ba}$ & $657.3 \pm 175.6 \mathrm{Ba}$ & $743.9 \pm 173.6 \mathrm{Ba}$ & $1993.0 \pm 234.6 \mathrm{Ba}$ \\
\hline & $\mathrm{T} 3$ & $758.1 \pm 345.0 \mathrm{Ba}$ & $788.7 \pm 192.5 \mathrm{Ba}$ & $668.5 \pm 222.3 \mathrm{Ba}$ & $2215.3 \pm 715.2 \mathrm{Ba}$ \\
\hline & $\mathrm{T} 4$ & $1270.1 \pm 305.0 \mathrm{Aa}$ & $1423.1 \pm 426.6 \mathrm{Aa}$ & $1075.5 \pm 141.9 \mathrm{Aa}$ & $3768.7 \pm 772.0 \mathrm{Aa}$ \\
\hline \multirow{4}{*}{ S. amazonicum } & $\mathrm{T} 1$ & $15.1 \pm 5.7 \mathrm{Ca}$ & $35.3 \pm 18.1 \mathrm{Ba}$ & $22.6 \pm 16.3 \mathrm{Ca}$ & $73.0 \pm 38.5 \mathrm{Ca}$ \\
\hline & $\mathrm{T} 2$ & $89.7 \pm 37.7 \mathrm{Bb}$ & $96.0 \pm 49.1 \mathrm{Bb}$ & $48.4 \pm 27.9 \mathrm{BCb}$ & $234.1 \pm 108.9 \mathrm{BCb}$ \\
\hline & $\mathrm{T} 3$ & $83.7 \pm 38.1 \mathrm{Bb}$ & $136.5 \pm 87.7 \mathrm{Bb}$ & $108.1 \pm 61.6 \mathrm{Bb}$ & $328.3 \pm 166.4 \mathrm{Bb}$ \\
\hline & $\mathrm{T} 4$ & $306.9 \pm 72.6 \mathrm{Ab}$ & $372.1 \pm 140.7 \mathrm{Ab}$ & $283.8 \pm 91.5 \mathrm{Ab}$ & $962.8 \pm 265.9 \mathrm{Ab}$ \\
\hline
\end{tabular}

Means of six plants $( \pm \mathrm{SD})$; mean values followed by the same letters did not differ significantly between treatments at $\mathrm{p} \leq 0.05$ based on Duncan's test. Within columns, uppercase letters compare the effects of the different fertilization treatments on each species, and lowercase letters compare the three species within the same fertilization treatment.

In terms of fertilization, both $I$. edulis and $S$. amazonicum responded better to the simultaneous application of both chemical and organic fertilizers (T4), while D. odorata assimilated more C under the T2 treatment. Under T4, I. edulis assimilated almost 47 times more $\mathrm{C}$ in its biomass (3768.7 g C plant ${ }^{-1}$ year $\left.^{-1}\right)$ compared to the unfertilized T1 treatment (80.7 $\mathrm{g} \mathrm{C} \mathrm{plant}^{-1}$ year $^{-1}$ ), and $S$. amazonicum assimilated 13 times more $\mathrm{C}(962.8$ g C plant $^{-1}$ year $\left.^{-1}\right)$ compared to the T1 $\left(73.0 \mathrm{~g} \mathrm{C}^{-1}\right.$ plant $^{-1}$ year $^{-1}$ ) treatment (Table I).

\section{POTENTIAL FOR CARBON SEQUESTRATION WITH FOREST RESTORATION}

We present four possible restoration scenarios based on our data: each species planted by itself and all three species planted together. Individually, I. edulis could potentially stock more $\mathrm{C}$ than the other two species, and when the T4 treatment data were extrapolated over hectares, I. edulis $(9.4 \mathrm{Mg}$ $\mathrm{C} \mathrm{ha}^{-1}$ year $^{-1}$ ) could assimilate 16 times more $\mathrm{C}$ than D. odorata $\left(0.6 \mathrm{Mg} \mathrm{C}^{-1}\right.$ year $\left.^{-1}\right)$ and almost 4 times more C than S. amazonicum (2.4 Mg C $\mathrm{ha}^{-1}$ year $^{-1}$ ) (Figure 1). Under the T2 treatment (chemical fertilization), which is the most common fertilization scheme in restoration forest plantations, I. edulis (5.0 Mg C ha ${ }^{-1}$ year $\left.^{-1}\right)$ could assimilate more than 8 times more $\mathrm{C}$ compared with the other two species (Figure 1).

If we consider the three species in combination, the $\mathrm{T} 2$ and the $\mathrm{T} 4$ treatments were able to assimilate 14 times (2.1 $\mathrm{Mg} \mathrm{C}^{-1}$ year $\left.^{-1}\right)$ and 29 times (4.1 $\left.\mathrm{Mg} \mathrm{C}^{-1} \mathrm{year}^{-1}\right)$ more $\mathrm{C}$, respectively, than the $\mathrm{T} 1$ treatment $\left(0.14 \mathrm{Mg} \mathrm{C}^{-1} \mathrm{year}^{-1}\right)$ (Figure 1). 


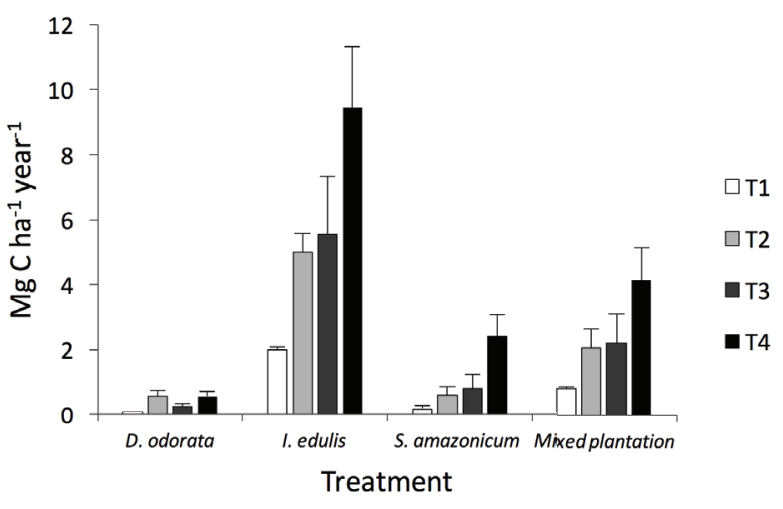

Figure 1 - C sequestration potential of the three tested species and a mixed plantation under the different fertilization treatments based on the total biomass (aboveground and root biomass). T1 - no fertilization, T2 - chemical fertilization, $\mathrm{T} 3$ - organic fertilization, and T4 - organic and chemical fertilization.

\section{LEAF NUTRIENT CONTENTS AND ASSIMILATION}

Significant differences in leaf nutrient contents were found among both species and fertilization treatments.

I. edulis had higher leaf $\mathrm{N}$ values than the other two tested species under all fertilization treatments, and for D. odorata and S. amazonicum, the highest values were observed under the T2 treatment (24.2 $\mathrm{mg} \mathrm{N} \mathrm{g}^{-1}$ and $21.5 \mathrm{mg} \mathrm{N} \mathrm{g}^{-1}$, respectively) (Table II). I. edulis had the highest leaf $\mathrm{P}$ values, and $D$. odorata had the lowest values.

The highest $\mathrm{K}$ values in the leaves were found for D. odorata under the T2 treatment. I. edulis had a higher $\mathrm{Ca}$ content than the other two species, and D. odorata had lower values than the other two species under all fertilization treatments (Table II). Additionally, I. edulis had higher leaf $\mathrm{Mg}$ values, but differences between I. edulis and S. amazonicum were only found under the T3 treatment.

As a N-fixing species, I. edulis stocked a greater proportion of its $\mathrm{N}$ in the leaves, so the higher biomass production combined with the higher $\mathrm{N}$ content of I. edulis under the T4 treatment (78.6 $\mathrm{g} \mathrm{N}_{\text {plant }}{ }^{-1}$ year $^{-1}$ ) resulted in the assimilation of almost 7 times more $\mathrm{N}$ than $S$. amazonicum $(11.7 \mathrm{~g}$
$\mathrm{N}_{\text {plant }}{ }^{-1}$ year $^{-1}$ ) and 20 times more than $D$. odorata (3.9 $\mathrm{g} \mathrm{N}$ plant $^{-1}$ year $^{-1}$ ) (Table III). If we consider an I. edulis monoculture in the available space, this species alone could assimilate $196.5 \mathrm{~kg} \mathrm{~N}^{-1}$ year ${ }^{1}$ in the leaf tissues, while $S$. amazonicum could assimilate $29.2 \mathrm{~kg} \mathrm{~N} \mathrm{ha}^{-1}$ year $^{-1}$ and D. odorata 9.7 $\mathrm{kg} \mathrm{N}^{-1} \mathrm{year}^{-1}$.

I. edulis also stored more $\mathrm{P}$ than the other two species. The highest proportional $\mathrm{P}$ values for the species were found under the T4 treatment (3.5 g P plant ${ }^{-1}$ year $^{-1}$ ), i.e., $8.7 \mathrm{~kg} \mathrm{P} \mathrm{ha}^{-1}$ year $^{-1}$ in leaf biomass. I. edulis also had higher $\mathrm{K}$ values under T4, reaching $20.3 \mathrm{~g} \mathrm{~K} \mathrm{plant}^{-1}$ year $^{-1}$ (Table III), which amounted to an additional $50.7 \mathrm{~kg} \mathrm{~K} \mathrm{ha}^{-1}$ year ${ }^{1}$.

Finally, I. edulis also stocked more leaf $\mathrm{Ca}$ and $\mathrm{Mg}$ per plant than the other two species; its highest $\mathrm{Ca}\left(26.5 \mathrm{~g} \mathrm{Ca} \mathrm{plant}^{-1}\right.$ year $\left.^{-1}\right)$ and $\mathrm{Mg}$ (4.6 g $\mathrm{Mg}$ plant $^{-1}$ year $\left.^{-1}\right)$ values were found under the T4 treatment (Table III). S. amazonicum had higher rates of Ca (6.5 $\mathrm{g} \mathrm{Ca} \mathrm{plant}^{-1}$ year $\left.^{-1}\right)$ and $\mathrm{Mg}(1.1$ g Mg plant ${ }^{-1}$ year $\left.^{-1}\right)$ assimilation under the T4 treatment.

\section{DISCUSSION}

The potential C stocks of tropical trees have been receiving the attention of the scientific community due to the role that tropical forests play in the global C cycle (Gibbs et al. 2007). Because of this function, degraded areas in Amazonian ecosystems can be used to establish restoration forest plantations that can provide both ecosystem services (C stocks) and goods (stem production) (Lamb et al. 2005, Guariguata and Brancalion 2014). Furthermore, combining species that exhibit rapid growth and biomass production with later-successional species that are capable of providing good stem quality can benefit local communities (Rodrigues et al. 2009).

The early successional species I. edulis can produce large quantities of biomass that, combined with the ability of the species to fix atmospheric 
TABLE II

Leaf nutrient contents of the three tested species under the different fertilization treatments in a forest restoration plantation in an area degraded by the Balbina Hydroelectric Dam, AM - Brazil. T1 - no fertilization, T2 - chemical fertilization; T3 - organic fertilization, and T4 - organic and chemical fertilization.

\begin{tabular}{|c|c|c|c|c|c|c|}
\hline \multirow{2}{*}{ Species } & \multirow{2}{*}{ Fertilization } & \multicolumn{4}{|c|}{ Variable } & \multirow[b]{2}{*}{ Mg } \\
\hline & & $\mathbf{N}$ & $\mathbf{P}$ & $\mathbf{K}$ & $\mathrm{Ca}$ & \\
\hline & & \multicolumn{5}{|c|}{ 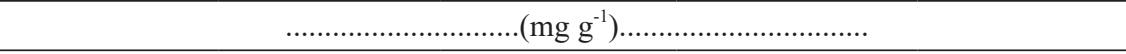 } \\
\hline \multirow{4}{*}{ D. odorata } & $\mathrm{T} 1$ & $14.8 \pm 3.6 \mathrm{Cb}$ & $1.0 \pm 0.2 \mathrm{Aa}$ & $7.4 \pm 1.3 \mathrm{Bab}$ & $3.1 \pm 2.2 \mathrm{ABc}$ & $1.0 \pm 0.2 \mathrm{Ab}$ \\
\hline & $\mathrm{T} 2$ & $24.2 \pm 2.2 \mathrm{Aab}$ & $0.9 \pm 0.1 \mathrm{Ac}$ & $12.1 \pm 1.3 \mathrm{Aa}$ & $4.3 \pm 1.1 \mathrm{Ab}$ & $0.9 \pm 0.2 \mathrm{Ab}$ \\
\hline & $\mathrm{T} 3$ & $16.4 \pm 2.1 \mathrm{BCb}$ & $0.9 \pm 0.1 \mathrm{Aa}$ & $10.3 \pm 1.9 \mathrm{Aa}$ & $2.4 \pm 0.5 \mathrm{Bc}$ & $1.0 \pm 0.2 \mathrm{Ac}$ \\
\hline & $\mathrm{T} 4$ & $19.0 \pm 2.3 \mathrm{Bb}$ & $0.8 \pm 0.1 \mathrm{Ab}$ & $10.3 \pm 1.6 \mathrm{Aa}$ & $4.0 \pm 0.8 \mathrm{ABb}$ & $1.1 \pm 0.3 \mathrm{Ab}$ \\
\hline \multirow{4}{*}{ I. edulis } & $\mathrm{T} 1$ & $25.4 \pm 5.3 \mathrm{ABa}$ & $1.2 \pm 0.8 \mathrm{Aa}$ & $5.1 \pm 1.4 \mathrm{Bb}$ & $8.4 \pm 2.4 \mathrm{ABa}$ & $1.9 \pm 0.4 \mathrm{Aa}$ \\
\hline & $\mathrm{T} 2$ & $27.8 \pm 2.1 \mathrm{ABa}$ & $1.3 \pm 0.1 \mathrm{Aa}$ & $6.8 \pm 0.9 \mathrm{Ab}$ & $7.2 \pm 2.0 \mathrm{Ba}$ & $1.7 \pm 0.4 \mathrm{Aa}$ \\
\hline & $\mathrm{T} 3$ & $25.1 \pm 2.3 \mathrm{Ba}$ & $1.2 \pm 0.2 \mathrm{Aa}$ & $7.6 \pm 0.5 \mathrm{Ab}$ & $10.9 \pm 2.4 \mathrm{Aa}$ & $1.9 \pm 0.1 \mathrm{Aa}$ \\
\hline & $\mathrm{T} 4$ & $29.1 \pm 2.7 \mathrm{Aa}$ & $1.3 \pm 0.2 \mathrm{Aa}$ & $7.5 \pm 1.1 \mathrm{Ab}$ & $9.8 \pm 2.7 \mathrm{ABa}$ & $1.7 \pm 0.1 \mathrm{Aa}$ \\
\hline \multirow{4}{*}{ S. amazonicum } & $\mathrm{T} 1$ & $15.7 \pm 1.0 \mathrm{Bb}$ & $1.0 \pm 0.2 \mathrm{Ba}$ & $7.9 \pm 1.4 \mathrm{Aa}$ & $5.0 \pm 0.9 \mathrm{Bb}$ & $1.6 \pm 0.4 \mathrm{Aa}$ \\
\hline & $\mathrm{T} 2$ & $21.5 \pm 3.8 \mathrm{Ab}$ & $1.0 \pm 0.1 \mathrm{Bb}$ & $8.0 \pm 1.4 \mathrm{Ab}$ & $5.2 \pm 1.4 \mathrm{Bab}$ & $1.5 \pm 0.2 \mathrm{Aa}$ \\
\hline & $\mathrm{T} 3$ & $15.8 \pm 1.9 \mathrm{Bb}$ & $1.1 \pm 0.2 \mathrm{Ba}$ & $8.1 \pm 1.0 \mathrm{Ab}$ & $6.7 \pm 2.4 \mathrm{Bb}$ & $1.4 \pm 0.3 \mathrm{Ab}$ \\
\hline & $\mathrm{T} 4$ & $18.0 \pm 2.1 \mathrm{Bb}$ & $1.3 \pm 0.1 \mathrm{Aa}$ & $6.9 \pm 1.0 \mathrm{Ab}$ & $9.9 \pm 3.2 \mathrm{Aa}$ & $1.7 \pm 0.3 \mathrm{Aa}$ \\
\hline
\end{tabular}

Means of six plants $( \pm \mathrm{SD})$; mean values followed by the same letters did not differ significantly between treatments at $\mathrm{p} \leq 0.05$ based on Duncan's test. Within the columns, uppercase letters compare the effects of the different fertilization treatments on each species, and lowercase letters compare the three species within the same fertilization treatment.

TABLE III

Macronutrient assimilation rates in the leaf tissues of the three tested species in a forest restoration plantation in an area degraded by the Balbina Hydroelectric Dam, AM - Brazil. T1 - no fertilization, T2 - chemical fertilization, T3 - organic fertilization, and T4 - organic and chemical fertilization.

\begin{tabular}{|c|c|c|c|c|c|c|c|}
\hline \multirow{2}{*}{ Species } & \multirow{2}{*}{$\begin{array}{l}\text { Fertil- } \\
\text { ization }\end{array}$} & \multirow{2}{*}{ Leaf biomass } & \multicolumn{5}{|c|}{ Variable } \\
\hline & & & $\mathrm{N}_{\text {leaves }}$ & $\mathrm{P}_{\text {leaves }}$ & $\mathrm{K}_{\text {leaves }}$ & $\mathrm{Ca}_{\text {leaves }}$ & $\mathrm{Mg}_{\text {leaves }}$ \\
\hline & & & \multicolumn{5}{|c|}{$\ldots \ldots \ldots \ldots \ldots \ldots . .\left(\right.$ g plant $^{-1}$ year $\left.^{-1}\right) \ldots \ldots \ldots \ldots \ldots \ldots$} \\
\hline \multirow{4}{*}{ D. odorata } & $\mathrm{T} 1$ & $8.7 \pm 3.9 \mathrm{Cb}$ & $0.13 \pm 0.0 \mathrm{Cb}$ & $0.01 \pm 0.0 \mathrm{Cc}$ & $0.06 \pm 0.0 \mathrm{Cb}$ & $0.03 \pm 0.0 \mathrm{Cb}$ & $0.01 \pm 0.0 \mathrm{Cb}$ \\
\hline & $\mathrm{T} 2$ & $206.9 \pm 60.0 \mathrm{Ab}$ & $5.0 \pm 0.9 \mathrm{Ab}$ & $0.2 \pm 0.0 \mathrm{Ab}$ & $2.5 \pm 0.5 \mathrm{Ab}$ & $0.9 \pm 0.2 \mathrm{Ab}$ & $0.2 \pm 0.0 \mathrm{Ab}$ \\
\hline & $\mathrm{T} 3$ & $85.1 \pm 29.8 \mathrm{Bb}$ & $1.4 \pm 0.3 \mathrm{Bb}$ & $0.08 \pm 0.0 \mathrm{Bc}$ & $0.9 \pm 0.2 \mathrm{Bb}$ & $0.2 \pm 0.1 \mathrm{Bc}$ & $0.08 \pm 0.0 \mathrm{Bc}$ \\
\hline & $\mathrm{T} 4$ & $205.3 \pm 57.5 \mathrm{Ac}$ & $3.9 \pm 0.8 \mathrm{Ac}$ & $0.2 \pm 0.0 \mathrm{Ac}$ & $2.1 \pm 0.4 \mathrm{Ac}$ & $0.8 \pm 0.2 \mathrm{Ac}$ & $0.2 \pm 0.1 \mathrm{Ac}$ \\
\hline \multirow{4}{*}{ I. edulis } & $\mathrm{T} 1$ & $40.0 \pm 22.0 \mathrm{Ca}$ & $1.0 \pm 0.4 \mathrm{Ca}$ & $0.05 \pm 0.0 \mathrm{Ca}$ & $0.2 \pm 0.1 \mathrm{Ca}$ & $0.3 \pm 0.1 \mathrm{Ca}$ & $0.08 \pm 0.0 \mathrm{Ca}$ \\
\hline & $\mathrm{T} 2$ & $1259.1 \pm 239.2 \mathrm{Ba}$ & $35.0 \pm 4.5 \mathrm{Ba}$ & $1.6 \pm 0.2 \mathrm{Ba}$ & $8.6 \pm 1.4 \mathrm{Ba}$ & $9.1 \pm 1.9 \mathrm{Ba}$ & $2.1 \pm 0.4 \mathrm{Ba}$ \\
\hline & $\mathrm{T} 3$ & $1612.9 \pm 725.8 \mathrm{Ba}$ & $40.5 \pm 11.0 \mathrm{Ba}$ & $1.9 \pm 0.6 \mathrm{Ba}$ & $12.3 \pm 3.1 \mathrm{ABa}$ & $17.6 \pm 5.9 \mathrm{ABa}$ & $3.1 \pm 0.8 \mathrm{ABa}$ \\
\hline & $\mathrm{T} 4$ & $2702.4 \pm 648.6 \mathrm{Aa}$ & $78.6 \pm 13.0 \mathrm{Aa}$ & $3.5 \pm 0.7 \mathrm{Aa}$ & $20.3 \pm 4.0 \mathrm{Aa}$ & $26.5 \pm 6.8 \mathrm{Aa}$ & $4.6 \pm 0.7 \mathrm{Aa}$ \\
\hline \multirow{4}{*}{$\begin{array}{c}S . \\
\text { amazonicum }\end{array}$} & $\mathrm{T} 1$ & $32.1 \pm 11.9 \mathrm{Ca}$ & $0.50 \pm 0.1 \mathrm{Ca}$ & $0.03 \pm 0.0 \mathrm{Cb}$ & $0.2 \pm 0.1 \mathrm{Ca}$ & $0.2 \pm 0.0 \mathrm{Ca}$ & $0.05 \pm 0.0 \mathrm{Ca}$ \\
\hline & $\mathrm{T} 2$ & $190.9 \pm 80.2 \mathrm{Bb}$ & $4.1 \pm 1.2 \mathrm{Bb}$ & $0.2 \pm 0.0 \mathrm{Bb}$ & $1.5 \pm 0.4 \mathrm{Bb}$ & $1.0 \pm 0.3 \mathrm{Bb}$ & $0.3 \pm 0.1 \mathrm{Bb}$ \\
\hline & $\mathrm{T} 3$ & $178.1 \pm 80.1 \mathrm{Bb}$ & $2.8 \pm 0.8 \mathrm{Bb}$ & $0.2 \pm 0.1 \mathrm{Bb}$ & $1.4 \pm 0.4 \mathrm{Bb}$ & $1.2 \pm 0.5 \mathrm{Bb}$ & $0.25 \pm 0.1 \mathrm{Bb}$ \\
\hline & $\mathrm{T} 4$ & $652.9 \pm 150.2 \mathrm{Ab}$ & $11.7 \pm 2.0 \mathrm{Ab}$ & $0.8 \pm 0.1 \mathrm{Ab}$ & $4.5 \pm 0.8 \mathrm{Ab}$ & $6.5 \pm 1.8 \mathrm{Ab}$ & $1.1 \pm 0.3 \mathrm{Ab}$ \\
\hline
\end{tabular}

Means of six plants $( \pm \mathrm{SD})$; mean values followed by the same letters did not differ significantly between the treatments at $\mathrm{p} \leq 0.05$ based on Duncan's test. Within the columns, uppercase letters compare the effects of the different fertilization treatments on each species, and lowercase letters compare the three species within the same fertilization treatment. 
$\mathrm{N}$, makes it a promising candidate for forest restoration plantations (Joslin et al. 2011, Lojka et al. 2012). S. amazonicum and D. odorata, which are later-successional species, are also of great ecological importance as they provide long-term biomass production and $\mathrm{C}$ storage in plantations. It is important to note that not all late-successional species grow satisfactorily in degraded areas (Jaquetti et al. 2016), but both D. odorata and $S$. amazonicum have shown significant development under fertilization treatments, which is indicative of their potential for planting in the region.

It seems that the ecological group of a species determines its biomass production and $\mathrm{C}$ storage; early successional species such as $I$. edulis have higher photosynthetic rates and $\mathrm{C}$ assimilation and can thus generate more biomass, especially in the early stages of development (Jaquetti et al. 2014). As the plantation matures, late-successional species can incorporate more $\mathrm{C}$ into their biomass, especially the stem component.

In a study of tropical species at La Selva Biological Station in Costa Rica, RedondoBrenes and Montagnini (2006) found similar C sequestration rates in a mixed, eleven-year-old plantation with mean values of $5.1 \mathrm{Mg} \mathrm{C} \mathrm{ha}^{-1}$ year $^{-1}$, and other values similar to those of our $\mathrm{T} 4$ treatment (4.1 Mg C ha ${ }^{-1}$ year $^{-1}$ ) were also found by Arias et al. (2011) in Costa Rica with mean values of $5.4 \mathrm{Mg} \mathrm{C}^{-1} \mathrm{year}^{-1}$ for the six study species at the same spacing. Higher $\mathrm{C}$ sequestration was found in a Populus spp. plantation in China after 10 years of establishment; the greatest $\mathrm{C}$ sequestration occurred at a spacing of $3 \times 3 \mathrm{~m}$ (1.111 individuals $\left.\mathrm{ha}^{-1}\right)$, at which the species exhibited mean values of 7.2 $\mathrm{Mg} \mathrm{C} \mathrm{ha}^{-1}$ year $^{-1}$ (Fang et al. 2007).

According to Saatchi et al. (2007), C stocks in natural Amazonian forest ecosystems range from 50 to $>200 \mathrm{Mg} \mathrm{Cha}^{-1}$; in our experimental region, values range from 125 to $150 \mathrm{Mg} \mathrm{Cha}^{-1}$. In the coastal Atlantic Forest of Brazil, C stocks in the aboveground live biomass can range from 94 to
$127 \mathrm{Mg} \mathrm{C} \mathrm{ha}{ }^{-1}$ depending on the altitude (Villela et al. 2012). Feldpausch et al. (2004) found high C sequestration rates in regenerating secondary forest in the Central Amazon with mean values of $11 \mathrm{Mg}$ ha $^{-1}$ year $^{-1}$, which is similar to that of $I$. edulis in T4 (9.4 Mg ha ${ }^{-1}$ year $\left.^{-1}\right)$. This is expected because secondary forests are primarily composed of early successional species. With the sequestration rates found in our study, it would take approximately 30 years to rebuild the natural $\mathrm{C}$ stocks of the degraded area, but new studies indicate that highly productive species, such as Clitoria fairchildiana, Inga edulis and Acacia mangium, have the potential to reduce the time needed to reach natural $\mathrm{C}$ stocks from 30 to 7 years or even less, depending on the composition of the species.

In the Amazon, where low soil fertility plays a crucial role in the development and biomass production of tree species, it is essential to choose the appropriate fertilization treatment by considering the costs and benefits of the various methods (Quesada et al.2012). Although the organic fertilization treatments in our study provided better results for at least two of the three species (probably due to changes in soil humidity and temperature combined with chemical improvements), this method still has limitations (Ferreira et al. 2009). A large amount of biomass must be present in the surrounding area for incorporation, and the human labor requirements are also a limiting factor that makes organic fertilization more expensive than chemical fertilization (Denich et al. 2005, Joslin et al. 2011). An alternative approach to overcome these limitations is to intercrop N-fixing Fabaceae trees that will act as a nursery for the development of non-N-fixing trees (Nichols et al. 2001, Nichols and Carpenter 2006).

In highly degraded areas, choosing $\mathrm{N}$-fixing species such as I. edulis is a great way to restore the soil $\mathrm{N}$ and $\mathrm{C}$ contents, which are directly related to the success of forest restoration (Hobbs and Harris 2001, Viana et al. 2014). The rapid recovery 
of other nutrients, especially $\mathrm{K}, \mathrm{P}, \mathrm{Ca}$ and $\mathrm{Mg}$, is fundamental to creating the conditions necessary for the reestablishment of natural regeneration in degraded areas (Feldpausch et al. 2004). It is also important to note that larger amounts of biomass and $\mathrm{C}$ were found to be stored in leaves compared to stems and roots in this study, which can be explained by the duration of the experiment since later plantings will allocate more $\mathrm{C}$ to the stem than to leaves. Thus, this pattern is expected to change as a plantation matures.

The tropical climate conditions in Amazonia, which include significant amounts of precipitation, favor plant development, but there is a dearth of basic data about the development of tropical species in degraded areas (Santos Junior et al. 2006). Our study shows that tropical species exhibit significant $\mathrm{C}$ storage and stem production potential, but additional studies are necessary to determine the best silviculture practices, such as the combination and arrangement of species, the fertilization treatment (different combinations), spacing and other aspects, that will facilitate better management and make Amazonia forest plantations more competitive with others worldwide.

\section{CONCLUSIONS}

Higher sequestration of $\mathrm{C}$ and other macronutrients by early successional species is important for successful forest restoration, but mixing other, later-successional species can provide long-term benefits to fulfill restoration goals. As an early successional, N-fixing species, I. edulis stocked more $\mathrm{C}$ and other nutrients than the other two tested species. However, S. amazonicum and D. odorata are also of great importance in forest restoration, as they can provide good stem quality and promote the cycling of other nutrients such as $\mathrm{K}$ and $\mathrm{Mg}$. Overall, the three study species showed significant $\mathrm{C}$ and nutrient sequestration in a degraded area and are recommended for use in forest restoration plantations in the Amazonian region.

\section{ACKNOWLEDGMENTS}

We are grateful to the Instituto Nacional de Pesquisas da Amazônia (MCTI-INPA) and the Conselho Nacional de Desenvolvimento Científico e Tecnológico (CNPq, Brazil) for supporting this study financially; J.F.C. Gonçalves is a $\mathrm{CNPq}$ researcher. We also thank AJE for revising the English manuscript.

\section{REFERENCES}

ACHARD F, EVA HD, STIBIG H, MAYAUX P, GALLEGO J, RICHARDS T AND MALINGREAU J. 2002. Determination of deforestation rates of the world's humid tropical forests. Science 297: 999-1002.

ARIAS D, CALVO-ALVARADO J, RICHTER D AND DOHRENBUSCH A. 2011. Productivity, aboveground biomass, nutrient uptake and carbon content in fastgrowing tree plantations of native and introduced species in the Southern Region of Costa Rica. Biomass Bioenerg 35: 1779-1788.

ASNER GP, KNAPP DE, BROADBENT EN, OLIVEIRA PJC, KELLER M AND SILVA JN. 2005. Selective logging in the Brazilian Amazon. Science 310: 480-482.

DAVIDSON EA ET AL. 2012. The Amazon Basin in transition. Nature 481: 321-328.

DENICH M, VLEK PLG, ABREU SÁ TD, VIELHAUER K AND LUCKE W. 2005. A concept for the development of fire-free fallow management in the Eastern Amazon, Brazil. Agric Ecosyst Environ 110: 43-58.

EMBRAPA. 2009. Manual de análises químicas de Solos, Plantas e fertilizantes. EMBRAPA: Brasília, 370 p.

FANG S, XUE J AND TANG L. 2007. Biomass production and carbon sequestration potential in poplar plantations with different management patterns. J Exp Manag 85: 672679.

FELDPAUSCH TR, RONDON MA, FERNANDES ECM, RIHA SJ AND WANDELLI E. 2004. Carbon and nutrient accumulation in secondary forests regenerating on pastures in Central Amazonia. Ecol Appl 14: S164-S176.

FERREIRA MJ, GONÇALVES JFC AND FERRAZ JBS. 2009. Photosynthetic parameters of young Brazil nut (Bertholletia excelsa H. B.) plants subjected to fertilization in a degraded area in Central Amazonia. Photosynthetica 47: 616-620.

FERREIRA MJ, GONÇALVES JFC, FERRAZ JBS, SANTOS JUNIOR UM AND RENNENBERG H. 2016. Clonal 
variation in photosynthesis, foliar nutrient concentrations, and photosynthetic nutrient use efficiency in a Brazil nut (Bertholletia excelsa) plantation. Forest Sci 62: 323-332.

GIBBS HK, BROWN S, NILES JO AND FOLEY JA. 2007. Monitoring and estimating tropical forest carbon stocks: making REDD a reality. Environ Res Lett 2: 1-13.

GONÇALVES JFC AND SANTOS JUNIOR UMS. 2005. Utilization of the chlorophyll $a$ fluorescence technique as a tool for selecting tolerant species to environments of high irradiance. Braz J Plant Physiol 17: 307-313.

GUARIGUATA MR AND BRANCALION PHS. 2014. Current challenges and perspectives for governing forest restoration. Forests 5: 3022-3030.

HOBBS RJ AND HARRIS JA. 2001. Restoration ecology: Repairing the earth's ecosystems in the new millennium. Restor Ecol 9: 239-246.

HOUGHTON RA, SKOLE DL, NOBRE CA, HACKLER JL, LAWRENCE KT AND CHOMENTOWSKI WH. 2000. Annual fluxes of carbon from deforestation and regrowth in the Brazilian Amazon. Nature 403: 301-304.

HOUGHTON RA. 2005. Aboveground forest biomass and the global carbon balance. Glob Chang Biol 11: 945-958.

HOUGHTON RA. 2012. Carbon emissions and the drivers of deforestation and forest degradation in the tropics. Curr Opin Env Sust 4: 597-603.

HUNT R. 1990. Basic Growth Analysis; Edward Arnold: London, UK, p. 112.

JAQUETTI RK, GONÇALVES JFC, FERRAZ JBS, FERREIRA MJ, SANTOS JUNIOR UM AND LACERDA CF. 2014. Green fertilization enhances the photosynthetic performance and the growth of leguminous trees for restoration plantation in central Amazon. Am J Plant Sci 5: 2497-2508.

JAQUETTI RK, GONÇALVES JFC, FERRAZ JBS, FERREIRA MJ AND SANTOS JUNIOR UM. 2016. Ecofunctional traits and biomass production in leguminous tree species under fertilization treatments during forest restoration in Amazonia. Forests 7: 76-86.

JOSLIN AH, MARKEWITZ D, MORRIS LA, DE ASSIS OF, FIGUEIREDO RO AND KATO OR. 2011. Five native tree species and manioc under slash-and-mulch agroforestry in the eastern Amazon of Brazil: plant growth and soil responses. Agrofor Syst 81: 1-14.

KARSTEN J, PETERS GP AND ANDREW RM. 2013. Attribution of $\mathrm{CO}_{2}$ emissions from Brazilian deforestation to consumers between 1990 and 2010. Environ Res Lett 8: $1-7$.

KINTISCH E. 2016. How a 'Godzilla' El Niño shook up weather forecasts. Science 352: 1501-1502.

LAMB D, ERSKINE PD AND PARROTTA JA. 2005. Restoration of degraded tropical forest landscapes. Science 310: 1628-1632.
LOJKA B, PREININGER D, VAN DAMME P, ROLLO A AND BANOUT J. 2012. Use of the Amazonian tree species Inga edulis for soil regeneration and weed control. J Trop For Sci 24: 89-101.

MACEDO MO, RESENDE AS, GARCIA PC, BODDEY RM, JANTALIA CP, URQUIAGA S, CAMPELLO EFC AND FRANCO AA. 2008. Changes in soil $\mathrm{C}$ and $\mathrm{N}$ stocks and nutrient dynamics 13 years after recovery of degraded land using leguminous nitrogen-fixing trees. For Ecol Manage 255: 1516-1524.

MALHI Y, ROBERTS JT, BETTS RA, KILLEN TJ, LI W AND NOBRE CA. 2008. Climate change, deforestation, and the fate of the Amazon. Science 319: 169-172.

MIYAZAWA M, PAVAN MA, MURAOKA T, CARMO FS AND MELLO WJ. 2009. Análise química de tecidos vegetais. In Manual de análise química de solos, plantas e fertilizantes. EMBRAPA, Brasília.

MOSS RH ET AL. 2010. The next generation of scenarios for climate change research and assessment. Nature 463: 747-756.

NICHOLS JD AND CARPENTER FL. 2006. Interplanting Inga edulis yields nitrogen benefits to Terminalia amazonia. For Ecol Manage 233: 344-351.

NICHOLS JD, ROSEMEYER ME, CARPENTER FL AND KETTLER J. 2001. Intercropping legume trees with native timber trees rapidly restores cover to eroded tropical pasture without fertilization. For Ecol Manage 152: 195209.

QUESADA CA ET AL. 2012. Basin-wide variations in Amazon forest structure and function are mediated by both soils and climate. Biogeosciences 9: 2203-2246.

REDONDO-BRENES A AND MONTAGNINI F. 2006. Growth, productivity, aboveground biomass, and carbon sequestration of pure and mixed native tree plantations in the Caribbean lowlands of Costa Rica. For Ecol Manage 232: $168-178$.

RODRIGUES RR, LIMA RAF, GANDOLFI S AND NAVE AG. 2009. On the restoration of high diversity forests: 30 years of experience in the Brazilian Atlantic Forest. Biol Conserv 142: 1242-1251.

ROWLAND L ET AL. 2015. Death from drought in tropical forests is triggered by hydraulics not carbon starvation. Nature 528: 119-122.

RUIZ-JAEN MC AND POTVIN C. 2011. Can we predict carbon stocks in tropical ecosystems from tree diversity? Comparing species and functional diversity in a plantation and a natural forest. New Phytol 189: 978-987.

SAATCHI SS, HOUGHTON RA, SANTOS ALVALÁ RC, SOARES JV AND YU Y. 2007. Distribution of aboveground live biomass in the Amazon basin. Glob Change Biol 13: 816-837.

SANTOS JUNIOR UM, GONÇALVES JFC AND FELDPAUSCH TR. 2006. Growth, leaf nutrient 
concentration and photosynthetic nutrient use efficiency in tropical tree species planted in degraded areas in central Amazonia. For Ecol Manage 226: 299-309.

SCHROTH G, D'ANGELO SA, TEIXEIRA WG, HAAG D AND LIEBEREI R. 2002. Conversion of secondary forest into agroforestry and monoculture plantations in Amazonia: consequences for biomass, litter and soil carbon stocks after 7 years. For Ecol Manage 163: 131150.

SIDDIQUE I, ENGEL VL, PARROTTA JA, LAMB D, NARDOTO GB, OMETTO JPHB, MARTINELLI LA AND SCHIMIDT S. 2008. Dominance of legume trees alters nutrient relations in mixed species forest restoration plantings within seven years. Biogeochemistry 88: 89-101.

SILVA CEM, GONÇALVES JFC AND ALVES EG. 2011. Photosynthetic traits and water use of tree species growing on abandoned pasture in different periods of precipitation in Amazonia. Photosynthetica 49: 246-252.

SOARES-FILHO B, RAJÃO R, MACEDO M, CARNEIRO A, COSTA W, COE M, RODRIGUES H AND ALENCAR A. 2014. Cracking Brazil's Forest Code. Science 344: 363364.
TAPIA-CORAL SC, LUIZÃO FJ, WANDELLI E AND FERNANDES ECM. 2005. Carbon and nutrient stocks in the litter layer of agroforestry systems in central Amazonia, Brazil. Agrofor Syst 65: 33-42.

THOMAS SC AND MARTIN AR. 2012. Carbon content of tree tissues: A synthesis. Forests 3: 332-352.

VIANA RM, FERRAZ JBS, NEVES AF, VIEIRA G AND PEREIRA BFF. 2014. Soil quality indicators for different restoration stages on Amazon rainforest. Soil Till Res 140: 1-7.

VILLELA DM, DE MATTOS EA, PINTO AS, VIEIRA SA, MARTINELLI LA. 2012. Carbon and nitrogen stock and fluxes in coastal Atlantic Forest of southeast Brazil: potential impacts of climate change on biogeochemical functioning. Braz J Biol 72(3): 633-642.

VISSEREN-HAMAKERS IJ, GUPTA A, HEROLD M, PENÃ-CLAROS M AND VIJGE MJ. 2012. Will REDD+ work? The need for interdisciplinary research to address key challenges. Curr Opin Environ Sustain 4: 590-596.

ZHAO D, OOSTERHUIS DM AND BEDNARZ CW. 2001. Influence of potassium deficiency on photosynthesis, chlorophyll content, and chloroplast ultrastructure of cotton plants. Photosynthetica 39: 103-109. 